\title{
ИССЛЕДОВАНИЯ AR-AR ИЗОТОПНЫХ СИСТЕМ В АМФИБОЛАХ РАННЕДОКЕМБРИЙСКИХ ПОРОД КОЛЬСКОГО РЕГИОНА
}

\section{Пожиленко В.И.}

Геологический институт КНЦ РАН, Anamuты, pozhil@geoksc.apatity.ru

Постановка и проведение исследований по изучению Ar-Ar и K-Ar систем в минералах (амфиболах, слюдах и др.) раннедокембрийских метаморфических и магматических пород Кольского региона была проведена в рамках программы международного проекта SVEKALAPKO группой исследователей, в которую кроме автора входили М. Тиммерман и С. Дейли (Ирландия), де Янг К. и Д. Рэкс (Англия).

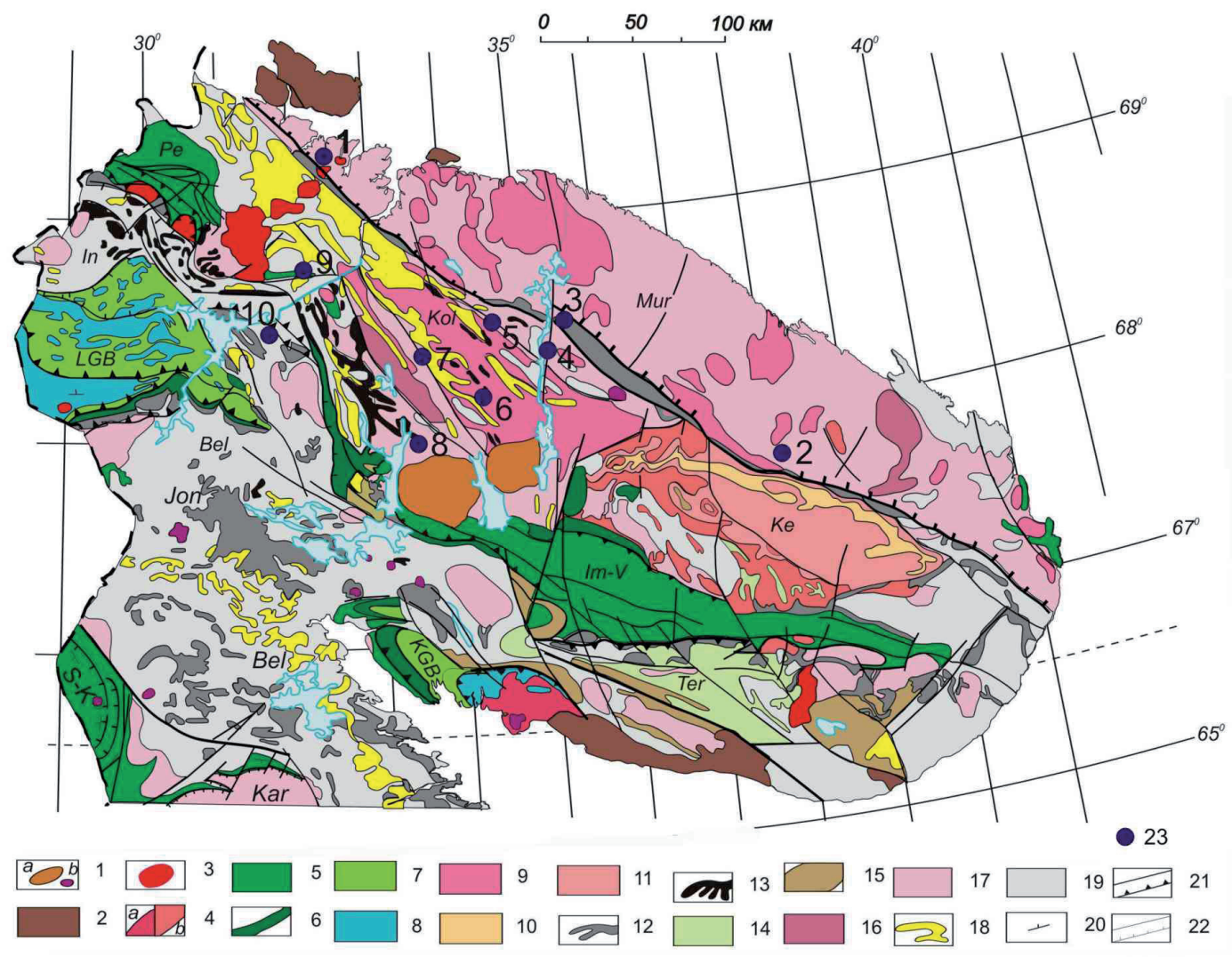

Рис.1. Положение точек отбора проб на упрощённой геологической карте Кольского региона

Балтийского щита, составленной В. И. Пожиленко на основе [1].

1 - палеозойские интрузии: 2 - осадочные породы верхнего протерозоя.

Ранний протерозой: 3 - граниты, гранодиориты и диориты; 4 - чарнокиты, граниты (а), щелочные граниты, в т.ч. позднеархейские в Кейвах (б); 5 - вулканогенно-осадочные породы; 6 - анортозиты, габбро-анортозиты (в Кейвах - архейские), габбро, пироксениты, перидотиты; 7 - гранулиты основного и среднего состава; 8 - кислые гранулиты.

Поздний архей: 9 - гранодиориты, диориты и эндербиты; 10 - глиноземистые и суперглиноземистые гнейсы и сланцы; 11 - кислые гнейсы; 12 - фрагменты зеленокаменных поясов (гнейсы, амфиболиты и метакоматииты); 13 - фрагменты железорудной формации (гнейсы, амфиболиты и железистые кварциты); 14 - гнейсы и сланцы; 15 - гнейсы и амфиболиты; 16 - гранодиориты и диориты; 17 - плагиограниты и гранито-гнейсы; 18 - кианит-гранат-биотитовые гнейсы; 19 - гранито-гнейсы, гнейсы, мигматиты и редко амфиболиты.

20 - элементы залегания. 21 - субвертикальные разломы и пологие надвиги, разделяющие протерозойские террейны. 22 - субвертикальные разломы и надвиги разной иерархии. 23 - положение точек отбора проб.

Террейны: Миг - Мурманский, Kol - Кольский, Bel - Беломорский, Ter - Терский, Кe - Кейвский, In - Инари. Пояса: архейские зеленокаменные: Јon - Енский, К-V - Колмозеро-Воронья; палеопротерозойские гранулитовые: LGB - Лапландский, KGB - Кандалакшско-Колвицкий; рифтогенные, палеопротерозойские: Ре - Печенга, Im-V - Имандра-Варзуга. 
Таблица 1. Время закрытия (млн. лет назад) Ar-Ar-изотопных систем в амфиболах из амфиболитов и привязка точек опробования.

\begin{tabular}{|c|c|c|}
\hline $\begin{array}{l}\text { Nọ } \\
\text { nin }\end{array}$ & $\begin{array}{l}\text { Номер пробы. Название породы пробы, ассоцнирующие с ней породы, } \\
\text { место отбора пробы. }\end{array}$ & $\begin{array}{l}\text { Возраст } \\
\text { (млн. лет) }\end{array}$ \\
\hline 1 & 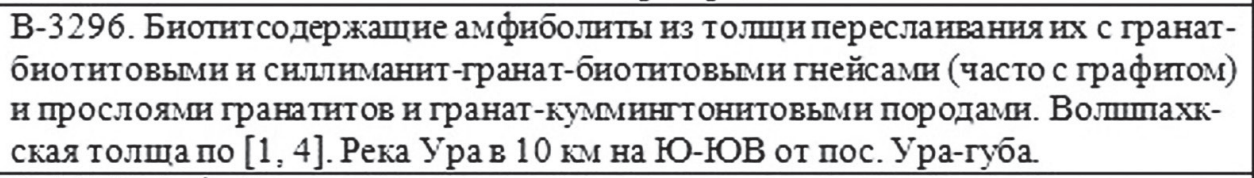 & $2772 \pm 17$ \\
\hline 2 & $\begin{array}{l}\text { В-2028. Амфнболиты из релнктовых линз теневых миматитов среди гранито- } \\
\text { гнейсов (тронпемнтов). Левый берег р. Йоканыги, Мурманскнй террейн. }\end{array}$ & $2042=8$ \\
\hline $3 a$ & $\begin{array}{l}\text { В-3513а. Прослой гранатовых амфиболитов из полмостундровской свиты по } \\
{[1,4] \text {, содержашей железистые кварциты. Зона Колмозеро-Воронья, в р-не }} \\
\text { г. Лешая и оз. Пельявр }\end{array}$ & $3336 \pm 17$ \\
\hline 36 & $\begin{array}{l}\text { В-3509. Амфибалиты с текстурами пиллоу-лав из полмостундровской свиты } \\
\text { по }[1,4] \text {. В } 160 \text { м к югу от точкн В-3513а. Зона Колмозеро-Воронья. }\end{array}$ & $5702 \pm 99$ \\
\hline $3 \mathrm{~B}$ & $\begin{array}{l}\text { В-3512. Полевошпатовые амфиболиты нз полмостундровской свиты по }[1,4] \text {. } \\
\text { В } 100 \text { м от точкн В-3513а. Зона Колмозеро-Воронљя. }\end{array}$ & $5692 \pm 35$ \\
\hline 4 & $\begin{array}{l}\text { В-3241. Амфноблиты. Прослой между тоналнто-гнейсамн и биотит- } \\
\text { гранатовымн гнейсамн. Волшпахкская толща по }[1,4] \text {. Кольскнй террейн. } \\
\text { Район рекн Чудзьйок. }\end{array}$ & $2526 \pm 9$ \\
\hline 5 & $\begin{array}{l}\text { В-3325. Амфиболиты среди кристаллосланцев с гнейсами и железистьми } \\
\text { кварцитами. Чудзьяврская толща по }[1,4] \text {. Центрально-Кольскнй блок, р-н оз. } \\
\text { Пинкельявр. }\end{array}$ & $2624 \pm 9$ \\
\hline 6 & $\begin{array}{l}\text { В-3555. Двупноксен-амфнболовый сланец среди глиноземпсых гнейсов. } \\
\text { Волшпахкская толша по }[1,4] . \text { Кольскнй террейн. } \\
\text { Западный берег оз. Чудзьявр. }\end{array}$ & $2443 \pm 9$ \\
\hline 7 & $\begin{array}{l}3576 . \text { Биотит-роговообманково-кварц-полевошпатовый гнейс из комплекса } \\
\text { основания по }[1,4] \text {. Центральная часть Центрально-Кольского блока Кольско- } \\
\text { го террейна. }\end{array}$ & $2510 \pm 8$ \\
\hline $8 a$ & $\begin{array}{l}\text { В-7194. Пачка амфибалитов срели гнейсов с железистьмн кварцитамн. Оле- } \\
\text { негорская толща по [1, 4]. Центрально-Кольскнй блок Кольского террейна. } \\
\text { Район Печ-губы оз. Имандра. }\end{array}$ & $2325 \pm 9$ \\
\hline 86 & $\begin{array}{l}\text { В-7108. Пачка амфнболнтов среди гнейсов с железистымн кварцитамн. } \\
\text { Центрально-Кальскнй блок Кольского террейна. Оленегорская толша по [1, } \\
\text { 4]. Район Печ-губы оз. Имаңдра, в } 105 \text { м к северу от т. В-7194. }\end{array}$ & $1890 \pm 185$ \\
\hline $8 \mathrm{~B}$ & $\begin{array}{l}\text { В-7190. Пачка амфиболнтов средн гнейсов с железистым кварцитамн. } \\
\text { Центрально-Кальский блок Кольского террейна. Оленегорская толша по } \\
{[1,4] \text {. Район Печ-губы в } 80 \text { м к северу от точкн В-7194. }}\end{array}$ & $2233 \pm 8$ \\
\hline 9 & $\begin{array}{l}\text { 1350. Титанит-скаполит-диопсид-роговообманковый амфиболит из толщн } \\
\text { сланцеватьх амфиболитов свиты кеулик-кенирим по }[1,4] \text {. Центрально- } \\
\text { Кольскнй блок Кольского террейна, р. Шовна. }\end{array}$ & $1748 \pm 9$ \\
\hline 10 & $\begin{array}{l}\text { 1379. Гранат-биотитовый амфнболит из толши гранатовьг амфнболштов } \\
\text { ёнского комплекса по }[1,4] \text {. Нотозерский блок Беломорского террейна. }\end{array}$ & $1877 \pm 7$ \\
\hline
\end{tabular}

Исследования преследовали несколько целей: выявление на уровне эрозионного среза среди раннедокембрийских пород Кольского региона неоднородности и разновозрастности термальных воздействий на Ar-Ar изотопную систему в разных минералах; определение времени закрытия и нарушений изотопных систем; определение скорости выведения комплексов пород на уровень эрозионного среза, неоднородности и возраста этих движений. Была отобрана большая коллекция минералов из разных пород, но, к сожалению, проанализирована была лишь незначительная часть из них.

Были исследованы образцы разных по составу пород Мурманского, Кольского и Беломорского террейнов, отобранные по меридиональному профилю вдоль автотрассы Мурманск-С-Петербург, а также минералы из коллекций О.А. Беляева, В.И. Пожиленко и др. Исследования минералов производили де Янг К. и Рэкс Д.Ч. (университет, г. Лидс, Англия). 
Наиболее общие выводы опубликованы в работах $[10,11,5,6]$. В этих-же тезисах изложена часть результатов работ по исследованию Ar-Ar и K-Ar изотопных систем в минералах Кольского региона - результаты исследований 14 амфиболов из коллекций О.А. Беляева и В.И. Пожиленко, выделенных из неоархейских амфиболитов Мурманского, Кольского и Беломорского террейнов и из палеопротерозойских амфиболитов свиты кеулик-кенирим (рис. 1, табл. 1).

Наиболее общие выводы по результатам Ar-Ar датирования амфиболов в целом подтверждают полученные в 1970-80-ых годах в Геологическом институте Кольского филиала РАН результаты. Породы Кольского региона в разных структурах подверглись термальному воздействию в раннем протерозое неравномерно: наиболее интенсивно в шовных зонах, в пределах развития раннепротерозойских пород и структур и в Беломорском террейне.

Спектры возрастов по роговым обманкам из Мурманского террейна характеризуются частичными термальными нарушениями и видимые датировки достигают максимального значения 2.65 млрд. лет, фиксируя позднелопийский возраст закрытия изотопной системы.

По направлению к шовной зоне Колмозеро-Воронья, где достаточно интенсивно проявились раннепротерозойские процессы, в целом возрастает нарушение лопийской изотопной системы и время закрытия Ar-Ar изотопных систем в роговых обманках становятся более молодым.

Амфиболы из амфиболитов зоны Колмозеро-Воронья имеют большие содержания избыточного аргона, низкое содержание калия. Поэтому отношения ${ }^{37} \mathrm{Ar} /{ }^{39} \mathrm{Ar}$ повышенные. Дискордантные видимые возраста этих амфиболов геологического смысла не имеют.

В возрастных Ar-Ar спектрах роговых обманок из Центрально-Кольского блока Кольского террейна картина более разнообразна, что является результатом более неравномерного раннепротерозойского термального воздействия. Часть спектров сохраняет датировки в интервале 2.6-2.5 млрд. лет, что может указывать на их позднелопийский возраст, т.е. на позднелопийское время охлаждения комплексов пород и закрытие изотопной системы. Амфиболы с возрастом 2.2-2.3 млрд. лет с частично нарушенной изотопной системой, с возрастом 1.87 млрд. лет - с полностью нарушенной изотопной системой. А возраст плато роговой обманки 1.77 млрд. лет из амфиболита вблизи южного края Центрально-Кольского блока датирует охлаждение, которое происходило после раннепротерозойского орогенеза.

Аналогичные возраста амфиболов из пород Беломорского террейна также указывают на полное нарушение изотопных систем в раннем протерозое и на калевийское время охлаждения и закрытия их $[10,11]$. То, что комплексы пород Беломорского террейна были выведены на более высокий гипсометрический уровень земной коры в свеко-феннское время палеопротерозоя, подтверждается также данными по датированию титанитов и рутилов [8].

Возраста 1.77 млрд. лет и 1.70 млрд. лет, соответственно для роговых обманок и мусковитов позволяют предположить, что скорость остывания Лапландско-Кольского раннепротерозойского орогена была около двух градусов на один миллион лет, т.е. очень низкой для тектонических областей с покровной тектоникой альпийского типа, которая была связана с коллизией плит [10]. Скорость остывания будет значительно выше ( $\approx 12^{\circ}$ на 1 млн. лет), если вести расчет от возраста гранулитового метаморфизма (1.95 млрд. лет) и возраста амфибола (1.75 млрд. лет) из пород Умбинского блока. U-Pb-возраст метаморфического циркона из эндербита Умбинского комплекса, рассланцованного в условиях гранулитовой фации, равен $1912 \pm 8$ млн. лет, тогда как в отдельных зернах ${ }^{207} \mathrm{~Pb} /{ }^{206} \mathrm{~Pb}$ возраста ядер, сложенных магматическим цирконом, составляют 1949 и 1966 млн. лет [7]. $\mathrm{Ar}-\mathrm{Ar}$ и Rb-Sr-возраст амфибола из Умбинского гранита равны соответственно $1889 \pm 8$ и $1882 \pm 15$ млн. лет [9]. По данным [3] остывание архейских пород Беломорского пояса начиная с 2730 до 1550 млн. лет происходило со средней скоростью $\sim 2{ }^{\circ} \mathrm{C} /$ млн лет. А возрасты метаморфических минералов 1.91-1.65 млрд. лет «отражают время вывода тектонических пластин со среднекоровых глубин в верхние уровни коры в ходе коллизионного развития Лапландско-Кольского орогена» [3].

В тоже время территории Мурманского и Кольского террейнов уже с позднелопийского времени являются областью высокого стояния и относительно стабильными на протяжении раннепротерозойского времени. Об этом свидетельствуют также результаты термоионного датирования 
цирконов [5] и лопийский возраст недеформированных даек Оленегорского района ЦентральноКольского блока Мурманского террейна [2].

Исследования выполнены в рамках темы НИР ГИ КНЦ РАН № 0231-2015-0004.

\section{Литература}

1. Геологическая карта Кольского региона (северо-восточная часть Балтийского щита) масштаба 1:500000. (Гл. ред. Ф.П. Митрофанов. Составители: Балаганский В.В., Басалаев А.А., Беляев О.А., Пожиленко В.И., Радченко А.Т., Радченко М.К.). Апатиты. 1996.

2. Егоров Д.Г., Баянова Т.Б. Возраст дайкового комплекса Кольской железорудной формации // Корреляция геологических комплексов Фенноскандии: Тез. докл. Междунар. конф. Санкт-Петербург, 8-11 сентября. 1996 г. СПб. 1996. С. 24.

3. Каулина Т.В. Термохронология пород для реконструкции развития подвижных поясов // Вестник Кольского научного центра РАН. 1/2012 (8). С. 111-114.

4. Объяснительная записка к геологической карте северо-восточной части Балтийского щита м-ба 1:500000 (Радченко А.Т., Балаганский В.В., Басалаев А.А., Беляев О.А., Пожиленко В.И., Радченко М.К.). Апатиты. Изд. КНЦ РАН. 1994. 95 с. (На русском и английском языках).

5. Пожиленко В.И., Баянова Т.Б., Богачев В.А., Гоголь О.В., Кощеев О.А., K. de Jong, D. Rex, M.J. Timmerman, J.S. Daly. Уточнение геотектонической природы и возраста раннедокембрийских процессов и пород по изотопным данным (Кольский регион, Балтийский щит) // Тезисы научной конференции «Изотопное датирование геологических процессов: новые методы и результаты», 15-17 ноября 2000 г., Москва. Изд. ИГЕМ РАН. 2000. С. 268-271.

6. Пожиленко В.И., Беляев О.А. Результаты исследования Ar-Ar и K-Ar изотопных систем в амфиболах пород Кольского региона (северо-восточная часть Балтийского щита) // Матер. международной научно-технической конференции «Наука и образование - 2008» Мурманск: МГТУ. 2008. С. 196-199.

7. Alexjev N.L., Salnikova E.B., Klepina S.V. Tectonic and P-T-time Evolution of the Kolvitsa-Umba Collision Zone // SVEKALAPKO an EUROPROBE project. 2nd Workshop. Lammi, Finland. 1997. Abstracts. University Oulu, Dep. Geophysics, Report № 21. 1997. P. 8.

8. Bibikova E.V., Skiold T., Bogdanova S.V., Gorbatchev R., Slabunov A. Titanite-rutile thermochronometry across the boundary between the Archaean Craton in Karelia and the Belomorian Mobile Belt, eastern Baltic Shield // Precam. Res. 2001. V. 105. P. 315-330.

9. Cliff R.A., de Jong K., Rex D.C., Guise P.G. Evaluation of Rb-Sr hornblende dating of rocks from the Kola Peninsula: an alternative to ${ }^{40} \mathrm{Ar}{ }^{39} \mathrm{Ar}$ where exess argon is present // Terra Nova. V. 9. Abs. Suppl. 1. 1997. P. 488.

10. De Jong K., Rex D.C., Guise P.G., Cliff R.A., Dali J.S., Timmerman M.J., Balaganski, V.V., Pozhilenko V.I. ${ }^{40} \mathrm{Ar}{ }^{39} \mathrm{Ar}$ mineral step-heating ages along a transect through the Lapland- Kola orogen and their implications for the Paleoproterozoic structuration of the Kola Peninsula // Abstracts. «Precambrian of Europe: Stratigraphy, Structure, Evolution and Mineralization», 9th Meeting of the AEGS, 4-15 Sept. 1995, St-Peterburg. - SPb, 1995. P. 28-29.

11. De Jong, K, MJ Timmerman, PG Guise, D Rex, RA Cliff, JS Dali, VV.Balagansky, and VI Pozhilenko. 1.7 Ga thermal resetting related to post-tectonic magmatism shown by ${ }^{40} \mathrm{Ar} /{ }^{39} \mathrm{Ar}$ mineral dating in the Paleoproterozoic Lapland-Kola Orogen (Russia) // SVEKALAPKO an EUROPROBE project, 4-th Workshop, Lammi, Finland, 1999. P. 19. 